\title{
Women's Cooperatives Contributions to Local Region Economy: Seferihisar Agricultural Cooperative Development Model-Turkey
}

\author{
Yasin Barut \\ Yasar University, Izmir, Turkey
}

\begin{abstract}
The cooperative movement has played a very important role in the social and economic development of all countries since 19th century's second half. Cooperatives provide health, housing, and banking services; they promote education and gender equality; they protect the environment and workers' rights. According to 2014's data, the total number of cooperatives is 79,486 in Turkey, while the total number of partners of cooperatives is approximately 7.8 million. The research's sample group "Hidirlik Agricultural Development Cooperative" was founded by the wife of the Seferihisar's mayor and six women. It has been a subject of curiousity that the contributions of the cooperative have developed the economy of the region since 2010. Therefore, various questions asked to the president and members of the cooperative, and significant results were obtained. In this research "Interview technique" was used. The fact that within the boundaries of local governments, the establishment of "women's cooperatives" and their active management can be supported with 10 basic criteria for the regional and national development can be predicted. These dimensions: ecological balance and sensitivity, the revival of the tourism sector, the mobility of logistics activities, new investments and increase of land value, the increase of women employment, the increase of healthy living standards, increase of competitiveness and trade earnings, the creation of new brands, widespread of the agricultural sector, and the increase of social and educational level of women. The similiar implementation of "Seferihisar Women's Cooperatives Model" in the research is considered form an important enterprenurship model not only in Turkey but also for all countries.
\end{abstract}

Keywords: women's cooperative, local region economics, women's enterprenurship, enterprenurship model

\section{Introduction}

Cooperatives emerged as economic organizations in the world during the middle of the 19th century. Rapid changes and transformation as a result of the Industrial Revolution, unemployment, domestic migration, urbanization, and economic and social problems such as the inequalities in income distribution contributed much to the emergence of cooperatives and they were introduced as a flow of consumers cooperatives by the workers in England which was the centre of the Industrial Revolution. During the recent years, France has followed England with the producers' cooperatives and Germany with artisans' and agricultural credit cooperatives.

In accordance with the Cooperatives Law No. 1163, a cooperative is defined in Turkey as follows (after an amendment in 2004): Cooperatives are bodies with variable members, variable capital, and legal identity that

Yasin Barut, Dr., Yasar University, Izmir, Turkey.

Correspondence concerning this article should be addressed to Yasin Barut, Yasar University, Izmir, Turkey. 
are established by natural and public legal entities and private administrations, municipalities, villages, societies, and associations in order to ensure and maintain certain economic interests and especially the needs of their members toward professional life and living standards by means of mutual assistance, solidarity, and service as trustees to each other.

Agricultural cooperatives are groups of farmers who bring resources together used to effectively capture the best product. Resources are, seeking marketing channels for seed during product cultivation, providing agricultural machinery, the moral and financial support of the members, and providing better and more fair prices. The purpose of creating cooperatives is to create a secure environment in terms of food safety and to improve the living standards among other members of society (Msimango \& Oladele, 2013).

Obstacles faced by women where in the most important condition for economic empowerment in the labor force participation and taking place gender inequality in economic power-sharing impoverished women day after day.

Existing examples of "loan application" in the world and in Turkey are widespread in order to prevent women's poverty. There needed education, counseling, guidance, and studies including providing fund-financing issues for women entrepreneurs.

Women's cooperative movement has started to be founded with demands of female entrepreneurs movement which comes from the base for bringing into economy of the female labor force, protection, support, and development of social and cultural activities of women, provision of better health and improved environment in the early 2000s in Turkey. This kind of cooperatives partnerships are $80-100 \%$ of women.

Among the main aims of the women's cooperatives establishment:

- Providing training to its partners to develop the right skills needed;

- Providing the necessary inputs and equipment for the production of partners' goods and services;

- Providing social and cultural needs to its partners, preparing the ground where healthy and an improved environment are provided.

\section{Literature Review}

\section{Women's Cooperative}

Cooperatives can be formed for a number of reasons. As long as there are common economic, social and/or cultural needs for which people feel it is advantageous to join together and form enterprises that are jointly owned and democratically controlled, and cooperatives are beneficial. Cooperatives can be classified in different ways based on a number of criteria such as the types of groups served, geographic territory served, industry, sector, functions performed, membership structure, legal status, and financial structure (Krivokapic-Skoko, 2002; Wissman, 1997).

Women's membership in most agricultural cooperatives in the region is concentrated usually in rather small numbers and in the lower ranks. In many cases, women have no voting power. This is usually vested in the "head of house" or the official land owner. Nor are women eligible to sit on management boards where key decisions are made. In a movement dedicated to improving a lot of disadvantaged workers, cooperative leaders have been slow to perceive, and too often resistant to change the disadvantaged position of women farmers (Stephens, 1995). 


\section{Women's Entreprenurship}

Schumpeter famously defined the entrepreneurship is carrying out of new combinations of firm organization-new products, new services, new sources of raw material, new methods of production, new markets, and new forms of organization. Entrepreneurship is also the control and deployment of resources to create an innovative economic organization (or network of organizations) for the purpose of gain or growth under conditions of risk and uncertainty (Dollinger, 2008).

Women entrepreneurs tend to operate in smaller businesses; usually go solo; tend to concentrate on sectors that are considered by financiers to be less profitable; tend to have lower growth and turnover compared to male-owned businesses. Women's entrepreneurship is both about women's position in society and the role of entrepreneurship in the same society. Women are faced with specific obstacles (such as family responsibilities) that have to be overcome in order to give them access to the same opportunities as men.

The rise of women entrepreneurship in industrialized economies is a recent phenomenon. The participation of women in economic life in developing countries contributes to a more human, cooperative, balanced, and pleasant work environment in women-led enterprises, in which individual development is engraved. Hisrich and Brush (1987) argued that an increasing number of women are seeking to penetrate the world of entrepreneurship, although this activity entails many risks, and the expenditure of time and energy. Numerous studies deal with the importance of women entrepreneurship in various regions in the world.

Cooperatives as a model of organization for women have been a very new, exciting, and active subject in Turkey. Women cooperatives are located from Naple to Iran in the world. Especially, in the countries which are underdeveloped economically, womens economic development is important for them (FAO Annual Report, 2003).

\section{Research Methods}

The research's sample group consists of six board members and chairman of the cooperative. In this research, the "interview technique" was used. Chairman and board members of the cooperative were asked: When and with whom they started the first cooperatives work? They consulted with whom? What kind of problems they faced? And how they reached this stage?

The objective of the research: determining what the contributions of the "Hidirlik Cooperative Agricultural Development" to develop the economy of the region of Seferihisar district of Izmir in Turkey since 2010. Also, this research involved members of cooperatives perceptions about their roles in cooperatives.

As a result of the research, it has been found that women's cooperative is contributing to the region with 10 basic criteria.

\section{Research Results}

As stated in the earlier, research questions were completly prepared by the researchers considering "cooperative literature".

The main problematics of the research determine: what problems women who established cooperative faced after the establishment stage? And once established, moreover observed that women entrepreneurship has more impact on the local development?

Ten main criteria were taken into consideration in the reseach. It transfers completely the thoughts of women's participating in speeches. Therefore, criteria have tried to describe formed from the resulting title. 


\section{Ecological Balance and Sensibility}

All individuals and organizations have their own responsibilities towards the environment they live. For example, a company has the responsibilities of not only its employees and the shareholders but also the environment.

Aktan (2008, p. 103) described organization's inner responsibility towards employees, shareholders, and executives along with this responsibility there are six other types of responsibilities that are the organization's external responsibility.

Accordingly, the main responsibilities of the company are nine. These are: 1). responsibility towards employees, 2). responsibility to shareholders, 3). responsibility towards managers, 4). responsibility with customers, 5). responsibility with opponents, 6). responsibility towards nature and the environment, 7). responsibility towards suppliers, 8). responsibility towards government, and 9). responsibility towards society.

In addition, Uydaci (2011, p. 129) underlined socially responsible companies are a subsystem of the extended social responsibility in marketing and, he stated that if desire and sustainable development can be harmonized with those of social responsibility.

Social marketing issues are marketing practice that the benefit of individual, group, or entire community affects the target audience. Then, social marketing issues are usually related to society (Özdoğan \& Eser, 2006, p. 4).

Maintaining the ecological balance, nowadays, the environment, air, and water pollution have become the topics to be considered by all people in society. Environment, air, water, and soil pollution seriously affects the balance of flora. Therefore, in the step of using the nutrients taken by people from the soil, these products are required to produce under natural conditions without adding harmful substances to the soil, habitat, and the goods produced (Yildiz, Spahi, \& Yilmaz, 2008, p. 14; Akdur, 2005, pp. 14-15; Karaca, 2008, p. 20; Keleş, Hamamci, \& Çoban, 2005, p. 110; Kalburan, 2013, p. 976).

\section{Revival of the Tourism Sector}

Tourism is one of the sectors who impellent to local economic development tanesidir (Özelçi \& Altinkaya, 2009 , p. 46). The development of the local economy depends on the tourism maybe in three ways (Rogerson, 2002, p. 95).

Firstly, especially fields intended on "Coastal tourism" are discovered by entrepreneurs who detect opportunities about improvement in these regions. Secondly, the small tourist towns are becoming touristic areas with the development of personal mobility, outside the initiative of local people. Finally, it is being developed in order to create employment and new job opportunitie (Inskeep, 1991, p. 10; Tosun, 2005, p. 336).

In the scope of this research, according to data received by the chairman and members of the cooperative, after completing the restoration of Seferihisar-Kaleiçi project, Izmir Metropolitan Municipality also has been providing support especially in terms of "Financing" the city's development topics and it has undertaken the huge costs that make the whole structure. Photographers have been started coming from all over the Turkey because of the visual presentation and aesthetics of these structures, increased interest in the recently opened boutique hotel. This situation has caused new jobs and increased the work force and field about "pensioning" in the district. All of these activities have helped Seferihisar be town to the "preferred" town for local tourism.

\section{The Mobility of Logistics Activities}

Essential situation for development of a country is investment, trade, and healthy operation of transport 
chain. Sustainable development depends on it. Ensuring the same level of transport and communications infrastructure all over the country, and spreading wealth centers all over the country have great importance on the development of the country's industry.

Development and growth on the form of national economy integrated into the region can only be achieved through improved transportation infrastructure (Logistics Industry Report, 2013, TUSIAD, 2005 Research Report 87).

According to the survey, women have started to sell grapes produced by them in their homes and gardens by "e-commerce". Naturally, the significant increase in the amount of ordering has been affected by logistics mobility in town.

Products, which women make and offered to customers living in Izmir and Istanbul through packages every day, have increased the number of "Cargo Business". Women in production, have began to advertise their product on "WEB Page" and they have started to sell "daily soilage" to Istanbul and "breakfast ingredients" to Izmir. In general, "Producer Market" founded Tuesday has also started to sell similar products. This situation has provided a new revenue opportunity for women. Customers from Izmir and the surrounding towns buying natural products have led women to make more sales and production. Thus, more production and sales causing an increase in the earnings of women have increased their self-confidence. Members have brought a certain standard for packaged products which counted in the cooperative. The cooperative has provided stronger than one's effort, because of the fact that women put a small commission such as $2 \%$ on the products they produce.

\section{New Investments and Increase of Land Value}

It is a known fact that women's employment is important in the development of a country. Today, women's employment has not reached the desired rate due to reasons, such as the pressures created by the gender roles and as a consequence of this within the family responsibilities to be undertaken largely by women, lack of education level, and limiting of women's employment owing to some results. Employment participation has a meaning beyond to earn money for a woman. Participation in employment is a prerequisite for standing on one's own two feet and self confidence of women (Publications of Women and Men Equal Opportunities Commission, 2013).

"Revolutionary Movement" has led to arrival of new investors. For example, "boutique hotel" and "pansioning" concept, created by residents of the district in the touristic area, have been attracting people from outside the city. This, naturally, has led to an increase of "land value" in the district.

\section{Increase of Women Employment}

A reason for not being at the desired level of female employment is that women can't benefit enough from educational opportunities. According to data from the year 2012, while labor force participation rate was $16.7 \%$ in non-literate women in the country, this ratio increased $30.6 \%$ in high school graduates, $38.1 \%$ in vocational and technical high school graduates, and $70.9 \%$ in higher education graduates. These data suggest that the level of education is important because it shows the relationship on labor force participation.

"Women's cooperatives" idea of the district mayor which women should participate in production in this city, is integrated with the question "what can we do" of female members. First, reaching the elderly of the city, and asking what were traditional dishes during the past years. For example, meals "gummy tarhana" is no longer appeared to be done. After that, it was decided to make the forgotten dishes again. Thus, "demanded and 
popular new flavors" (noodles, jam, soap, olives, and olive oil) have become among the demanded products for customers coming to shopping arcade.

In 2000, small market stalls, which began operating with 10 , have become a place visited by hundreds of customers today. Having more visitors coming to take "Organic Products" with various crafts made by women who have also led to activation of their husband. Formerly, men usually were sitting "coffeehouse" but, now they supported their wives, and they had started to participate. This situation, the increase of "women's cooperatives" or "women producers" maybe become the largest output for the country's economy. This sector is the only effective sector in which women mobilized men.

\section{Increase of Healthy Living Standards}

In recent years, both plants and animal production have begun to harm the environment, animals, and humans. In contrast, organic production protects the environment and health, and reduces global warming in 37\% (S. Ünal, http://orgprints.org/25212). In 2000, it was carried out on eight million hectares of organic farming in the world, But today, organic production is carried out in more than 110 countries over 31.8 million hectares with 623,174 certified manufacturer. Organic agriculture has begun in 1984-1985 in Turkey with demand from abroad. Raisins, dried figs, and dried apricots are the first organic product.

Especially, in the last 10 years, production method also known as "organic agriculture" and "good farming" caused a more active action in this region. An interesting development behind this change has been realized with "seed swap rules". When purchases of local seeds were banned in the country, the villagers compulsorily began to take seed imported from abroad. But these seeds were not preferred, because of both unhealthy and not the desired product quality. More importantly, even the villagers have begun to move away from agriculture because of this negative atmosphere.

Therefore, a method has been developed for increasing the production and sale of "organic agriculture" products. Organic seeds stored in previous years, changing hands, have begun to find new owners with "clearing procedure". Thus manufacturer, getting seeds produced the "seed centers", produces more healthy and high quality fruit and vegetables. These products haven't sold in "Bazaar" formed only on Sunday. Also, selling has been started in "producer bazaar" (spices, fruits, vegetables, honey, herbs, pickles, bread, cheese, eggs, etc.) on Tuesday. This situation has caused customers to come from neighboring districts. This means that the products produced have enabled easier sales.

"Agriculture Panel" has been established by the council, because of providing "self-control" among people in the city about both the quality and sales. Manufacturers who don't comply with "declaration of food" have been punished. Firstly, every manufacturer, wishing to sell, must take the "Health Card" from municipality. Otherwise, they will not sale anything. For example, it is forbidden to put "glucose" instead of sugar in sweet products such as jam and so on. If they do not comply, they will be punished immediately.

\section{Increase of Competitiveness and Trade Earnings}

Support of entrepreneurship in Turkey is a phenomenon that began with the accession process European Union (Eren, 2002, p. 369). In terms of improving the distribution of income, entrepreneurship is encouraged, especially in rural areas and less developed regions.

Cooperative is a kind of partnerships, which cooperation with economic and social opportunities for achieving a common goal, by bringing together solidarity and bail. A Turkish goal that is not included in the economic potential of women is to be activated for increase prosperity. It is important that ensuring cooperation 
between women entrepreneurs own, and creating national, regional, and international levels in the organization and collaboration.

According to the Government Policy in 2010, approximately, 100 establishments of "Women, Environment, Culture, and Business Cooperative" are desirable in the country each year. Thereby, women will be able to find opportunity about working, producing, and gaining economic income in cooperatives established from them. Turkey Cooperative Strategy and Action Plan were prepared under the coordination of the Ministry, and emphasis on women's cooperatives; studies were conducted about organizing under the roof of cooperatives for provision of female entrepreneurship and enhancing the ability of the economy to take part in as an actor (Cooperatives and Women's Cooperatives Booklet, 2012).

\section{Creation of New Brands}

Cooperative members, having affluent fields in terms of vineyards (Kavacik Üzüm Karasi) surrounding the city, wrote a project about how to start "wine production" to Development Agency (institutions supported by the state). However, they could not get any positive response in this regard, changing the scope of the project, they produced "Molasses" and tried to create new a "brand". Also, they used grapes in the "pastry industry", and they had created opportunity as a secondary market.

\section{Widespread of the Agricultural Sector}

People living in Seferihisar realized money earned from agriculture. So that, the number of people that wish to migrate to big cities with children has been decreased. People, seeded in the field with a "uniform product" (for example, only tomato), in the past, nowadays plant easier and quicker products like fruits and vegetables in area that they found empty. So that, they are looking for a way to increase their income.

\section{Increase of Social and Educational Level of Women}

The expansion of trade activities in the city has expanded economic level of women participating in production, thereby visibility of women in social life has been increased. The increase of earnings has increased the desire of women to educate their children and grandchildren. Female students have encouraged to go to "university" because of close to Izmir and economic freedom. This situation has begun to cause increasing number of highly educated women in the district.

\section{Conclusion}

There are some reasons why women's cooperative is so successful in Seferihisar district which is close to Izmir. The first and perhaps the most important is the district mayor. The mayor's most important project is "Slow-City Project". He has done a serious work for Seferihisar in order that "brand city".

The second is that the wife of the mayor who is founding president of the women's cooperative and has given seriously support to spouse. In this research, the most important issues to be taken into consideration for creating a city brand in local municipalities is that the role of the local authorities is very important.

According to the outcomes of the study, "women's cooperatives" is an acceptable "sustainable major source" for the country's economy. Also, particularly in terms of women and children, it is social policy and important formation that increase the level of development.

Therefore, this research has shown that all "added value products", "from agriculture", and "derived from agricultural products" in the development phase of the development level of countries will be able to be a serious "leading force" to both local and regional development of the country. 


\section{References}

Akdur, R. (2005). Environmental policy: The European Union and in Turkey adaptation of Turkey to the European Union ATAUM research series, No. 23. Ankara: Ankara University Press.

Aktan, B. (2008). Financial performance impacts of corporate entrepreneurship in emerging markets: A case of Turkey. European Journal of Economics, Finance and Administrative Sciences, p. 103.

Cooperatives and Women's Cooperatives Booklet. (2015). The Ministry of Customs and Trade Press.

Dollinger, M. J. (2008). Entreprenurship strategies and resources. Illinois, USA: Kelley School of Business Indiana University Marsh Publications Lombard.

Eren, F. (2002). The role of entrepreneurship in local local economic development: Case of Gaziantep. Session 1D: Mikroekonomi I. International Conference on Eurasian Economies, p. 369.

FAO Annual Report. (2003). Retrieved from http://www.fao.org/statistics/en/

Hisrich, R. D., \& Brush, C. G. (1987). Women entrepreneurs: A longitudinal study. Frontiers in Entrepreneurship Research, pp. 187-189. Wellesley, MA: Babson College.

Inskeep, E. (1991). Partnerships, Meso-Institutions and learning new local and regional economic development initiatives in Latin America. Institute of Social Studies, The Hogue, The Netherlands.

Kalburan, Ç. (2013). Management approach to ecological environment-friendly: Case of Unilever. International Conference Economies, p. 976.

Karaca, C. (2008). Approaches to environmental problems and solutions framework of environment, human and ethical. Cukurova University, Faculty of Economics Journal, 12(1), 19-33.

Keleş, R., Hamamci, C., \& Çoban, A. (2005). Environmental policy. Ankara: Imge Publishing.

Krivokapic-Skoko, B. (2002). The concept and classifications of agricultural co-operatives. ACCORD Paper, No. 8. Charles Stuart University, Bathurst.

Msimango, B., \& Oladele, O. I. (2013). Factors influencing farmers' participation in agricultural cooperatives in Ngaka Modiri Molema District, Department of Agricultural Economics and Extension, North-West University, Mafikeng Campus, South Africa. J Hum Ecol, 44(2), 113-119.

Özdoğan, B. F., \& Eser, Z. (2006). Social marketing. Ankara: Political Publications.

Özelçi, E., \& Altinkaya, Ö. (2009). Beypazari tourism development and local economic development. Economic and Social Research Journal, 5(2), 46-74.

Rogerson, C. M. (2002). Tourism-led local economic development: The South African experience. Viban Forum, 13, 95-119.

Stephens, A. (1995). Gender issues in agricultural and rural development policy in Asia and the Pacific. Gender Issues in Agricultural Development Policy in Asia and the Pacific, FAORAP, Bangkok.

Tosun, C. (2005). Stages in the emergence of a participatory tourism development approach in the developing world. Geoforum, $36,333-352$.

Uydaci, M. (2011). Green marketing. Ankara: Seckin Publications.

Wissman, R. A. (1997). Marketing coordination in agricultural cooperatives. Rural business cooperative service, research report 159, USA.

Women and Men Equal Opportunities Commission Publications. (2013). Enhancing women's employment in each area and suggestions committee report, No. 12.

Yildiz, K., Spahi, Ş., \& Yilmaz, M. (2008). Environmental science and education. Ankara: Gunduz Education and Publishing. 